\title{
SZABÁLYOZÓ SZELEPEKEN VALÓ ÁTÁRAMLÁS VIZSGÁLATA TÉVES SZELEPNYITÁS ESETÉN
}

\author{
Mikáczó Viktória \\ tanársegéd, Miskolci Egyetem \\ Energetikai és Vegyipari Gépészeti Intézet, Vegyipari Gépészeti Intézeti Tanszék \\ 3515 Miskolc, Miskolc-Egyetemváros, e-mail: mikaczo.viktoria@uni-miskolc.hu

\section{Pusztai Tamás} \\ PhD hallgató, Miskolci Egyetem \\ Energetikai és Vegyipari Gépészeti Intézet, Vegyipari Gépészeti Intézeti Tanszék \\ 3515 Miskolc, Miskolc-Egyetemváros, e-mail:vegypt@uni-miskolc.hu
}

\begin{abstract}
Absztrakt
Ipari megbizások tapasztalatai alapján merült föl a probléma, miszerint az egyes szabályozó szelepgyártó cégek által ajánlott méretezési segédlet segitségével meghatározott, az adott szelepen átáramló maximális tömegáram alulbecsüli mind a valós, mind az EN 60534 szerint számitott értéket, igy biztonságtechnikai számítások elvégzésére nem, vagy csak korlátozottan alkalmas. Jelen cikkünkben öszszevetettük ezek eredményeit az EN 60534 szabvány szerinti számitásokkal, valamint az ARI Armaturen szerelvénygyártó vállalat saját méretezöszoftverének, és a ChemCad szimulációs szoftver által adott eredményekkel. Vizsgálatainkat $20^{\circ} \mathrm{C}$ hömérsékletü vizre és nitrogénre végeztük el. A szabályozó szelepbe érkezö közeg nyomását 3 bar a és 30 bar a között változtattuk, míg a kilépö nyomást 2 bar $_{a}$ értéken tartottuk. A „,V-port plug” kialakitású ülékkel ellátott elzárószelep (,,globe” típusú) maximális átáramlási tényezőjét minden esetben $K_{V S}=100$ értékünek vettük.
\end{abstract}

Kulcsszavak: nyomásszabályozó szelep, biztonságtechnika, tömegáram, EN 60534

\begin{abstract}
The authors met the following problem in connection with previous industrial assignments: the maximum mass flow through a given pressure control valve which determined according to a sizing guide recommended by some control valve manufacturer, underestimates both the actual value and the value calculated according to EN 60534. In this article, the authors compared these estimations with the calculations according to the EN 60534 standard, as well as with the results provided by the ARI Armaturen fitting manufacturer's own sizing software and the ChemCad simulation software. Our tests were performed on water and nitrogen at $20^{\circ} \mathrm{C}$. Pressure of the medium entering the control valve was varied between 3 bar $_{a}$ and 30 bar $_{a}$, while the outlet pressure was kept at 2 bar $_{a}$. The maximum flow factor of a globe type valve with V-port plug was taken to be $K_{V S}=100$ in each case.
\end{abstract}

Keywords: pressure control valve, process safety, mass flow, EN 60534

\section{Bevezetés}

A vegyipari rendszerek üzemeltetéséhez segédáramokra van szükség. Ilyen tipikus segédáramok például a különböző nyomásfokozatú nitrogén- vagy müszerlevegő hálózatok, eltérő nyomással rendelke- 
ző gőzhálózatok, vagy például az ioncserélt vizek, valamint a fütőolajok körei. Jól látható, hogy mind folyadék, mind gőz/gáz halmazállapotú közegek is kiszolgálják a rendszereket.

Az egyes segédáram hálózatok a különböző nyomásfokozatú hálózati részek kiszolgálásához szükséges nyomásszabályzókat (PCV - Pressure Control Valve) tartalmaznak. A nyomásfokozatok veszélyes túlnyomását biztonsági szelepek (PSV - Pressure Safety Valve) korlátozzák, amelyek feladata, hogy a nyomásszabályzó rendellenes müködése esetén se növekedhessen a nyomás a védett alrendszerben a megengedettnél magasabb értékre. (1. ábra)

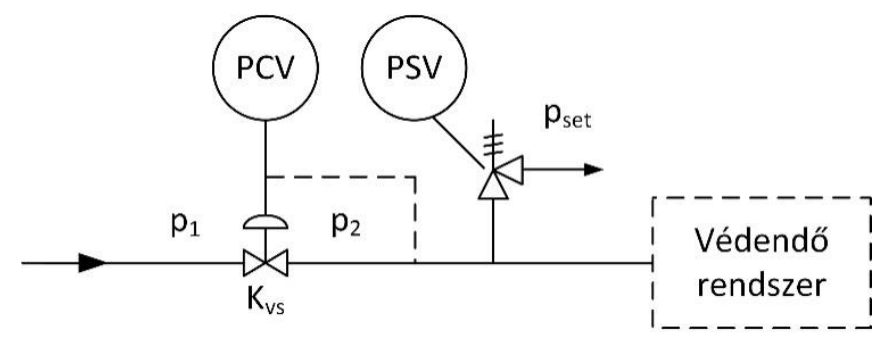

1. ábra Nyomásszabályozó után beépitett biztonsági szelep

\section{Szabályozó szelepek kapacitása és átáramlási tényezője}

Egy tipikus PCV nyomásszabályzó szelep és környezete látható az 1. ábraán. Amennyiben a védendő rendszer készülékeinek engedélyezési nyomása nem haladja meg a PSV biztonsági szelep $P_{\text {set }}$ nyitónyomásának értékét, a készülékeket hálózati nyomás megváltozásából eredő zavar nem veszélyezteti. A biztonsági szelepekre érvényes nyitó- és lefúvónyomás értékeket az API 520 szabvány 1. része szabályozza. [1] A szelepek nyitónyomását általában a védendő készülék vagy rendszer tervezési vagy engedélyezési nyomásához, vagy pedig - amennyiben a maximális üzemi nyomásnál ez jelentősen magasabb - a maximálisan megengedett üzemi nyomás értékéhez szokás illeszteni. Mint látható, általános előírás nincs, amely meghatározná, hogy egy adott nyomású hálózat esetén mekkora legyen a nyitónyomás értéke. [2] A beépített biztonsági szelepen szükség esetén veszélyelemzéssel határozzuk meg a lefúvatandó tömegáramot, ezt biztonsági okokból a szabályozó szelep teljes nyitottsága mellett átjutó tömegáram értékére vagy a fölé választjuk.

Egy $K_{V}$ átfolyási tényező értékkel jellemezhető szabályozó szelep a $P_{1}$ nyomást úgy redukálja $P_{2}$ nyomásra, hogy megfelelő áramlási felületet biztosít az áramló közegnek. A $K_{V}$ tényező megmutatja a szelepen egy adott szelepállás mellett 1 bar $_{\mathrm{g}}$ nyomáskülönbség hatására átáramló, $1000 \mathrm{~kg} / \mathrm{m}^{3}$ sủrüségü közeg térfogatáramát.

Kavitációmentes és turbulens átáramlás esetén, amennyiben a csatlakozó vezeték névleges mérete megegyezik a szabályozó szelep névleges méretével, a szelepen átáramló tetszőleges folyadék halmazállapotú közegre meghatározható az átfolyási tényező: [3]

$$
K_{V}=Q \sqrt{\left(\frac{\Delta p_{k v}}{\Delta p}\right)\left(\frac{\rho}{\rho_{w}}\right)}
$$

ahol

$Q$ az aktuálisan mért térfogatáram, $\mathrm{m}^{3} / \mathrm{h}$;

$\Delta p_{k v}$ a $105 \mathrm{~Pa}$ értékủ statikus nyomásveszteség a szelepen;

$\Delta p$ a mért statikus nyomásveszteség a szelepen, $\mathrm{Pa}$;

$\rho$ a vizsgált folyadék sürüsége, $\mathrm{kg} / \mathrm{m}^{3}$;

$\rho_{w}$ a víz sürüsége, $1000 \mathrm{~kg} / \mathrm{m}^{3}$-nek véve. 
Abban az esetben, ha a szabályozó szelep meghibásodik (például a szabályozásért felelős membrán megsérül) és teljesen nyitott állásba kerül, a védendő rendszerben nem kívánt nyomásemelkedés jöhet létre. A szabályzószelepekre a gyártók közlik a teljesen nyitott állásra vonatkozó $K_{V S}$ értéket, amely lehetővé teszi, hogy számítással meghatározásra kerüljön az ebben az esetben átáramló közeg mennyiségének meghatározása.

Esetenként az átáramlási tényező $C_{V}$ formában kerül megadásra. Ekkor a két érték átszámítható egymásból a következő módon:

$$
\frac{K_{V}}{C_{V}}=0,865
$$

A biztonsági szelep szükséges lefúvató teljesítményét ilyen esetben úgy kell meghatározni, hogy feltételezzük, hogy a PCV szelep előtt $P_{1}$, utána a $P_{\text {set }}$ nyomás alakul ki. A $K_{V S}$ segítségével meghatározható ebben az esetben a szelepen átáramló anyagmennyiség, mely megegyezik a biztonsági szelep által szükséges lefúvó teljesítménnyel. Abban az esetben, ha szelepnyitás mértéke korlátozható és kizárható a korlátozás megszüntetése, a korlátozott szelepálláshoz tartozó $K_{V}$ értékkel lehet a lefúvó teljesítményt meghatározni.

A szabályzószelepen átáramló anyagmennyiség például a EN 60534 szerint [4] számítható. A nagyobb szerelvénygyártók többsége (például az Ari Armaturen vagy a Crane) szintén ezt a szabványt használja és ajánlja méretezési feladatok megoldásához. Azonban bizonyos források [5] [6] egyszerüsített számítási összefüggéseket ajánlanak, és korábbi ipari megbízások kapcsán ezek alkalmazása is felmerült.

\section{Gyártói ajánlások}

A fejezet a Samson [5], illetve más gyártók és gyakran használt online adatbázisok [6] által ajánlott egyszerüsített számítási összefüggéseket foglalja össze a különböző halmazállapotú közegek esetén. Az általuk kiállított számítási segédletekben a javasolt összefüggések alapjául az EN 60534 szabványt jelölik meg. Nem veszik figyelembe a csatlakozó szerelvények hatását és a kritikus kiáramlás tömegáramot korlátozó hatását.

Azonban meghibásodás vagy a rendszerben bekövetkező valamely nyomásnövekedést okozó zavar esetén a kritikus áramlásra vonatkozó feltétel felborulhat, a szabályozó szelepben kavitáció is kialakulhat. [7]

\subsection{Folyadékok}

Folyadékok esetén adott nyomásviszonyok között a szelepen átáramló tömegáram:

$$
\mathrm{Q}=K_{V} \cdot \sqrt{1000 \cdot \rho \cdot\left(P_{1}-P_{2}\right)}
$$

ahol

$Q \quad$ a szelepen átjutó folyadék tömegárama, $\mathrm{kg} / \mathrm{h}$;

$K_{V}$ adott szelepnyitás melletti átfolyási tényezö;

$P_{1} \quad$ a szelep belépő oldali nyomása, bar $_{a}$;

$P_{2}$ a szelep kilépő oldali nyomása, bar ${ }_{a}$;

$\rho$ a folyadék sürüsége, $\mathrm{kg} / \mathrm{m}^{3}$. 


\subsection{Gázok, gőzök}

Gázok esetén adott nyomásviszonyok között a szelepen áthaladó közegáram mennyisége az alábbi egyelnetek segítségével számítható. Amennyiben kritikus alatti a nyomásviszony, azaz az egyszerüsített gyártói ajánlások szerint teljesül a $P_{2}>\frac{P_{1}}{2}$ reláció, a szabályozó szelepen átjutó térfogatáram:

$$
Q=\frac{519 \cdot K_{V}}{\sqrt{\frac{T}{\rho \cdot\left(P_{1}-P_{2}\right) \cdot P_{2}}}}
$$

Kritikus állapotot elérő gázáramlás esetén, azaz az egyszerüsített ajánlás szerint $P_{2}<\frac{P_{1}}{2}$ teljesülésekor a térfogatáram:

$$
Q=\frac{259,5 \cdot K_{V} \cdot P_{1}}{\sqrt{\frac{T}{\rho}}}
$$

ahol

$Q \quad$ a szelepen átjutó gáz tömegárama, $\mathrm{kg} / \mathrm{h}$;

$K_{V}$ adott szelepnyitás melletti átfolyási tényező;

$P_{1} \quad$ a szelep belépő oldali nyomása, bar $_{a}$;

$P_{2} \quad$ a szelep kilépö oldali nyomása, bar $_{a}$;

$T$ a gáz hömérséklete a szelep belépö oldalán, K;

$\rho$ a gáz normálsürüsége $\left(0^{\circ} \mathrm{C}\right.$ hőmérsékleten és 1013 mbar $_{\mathrm{a}}$ nyomáson $), \mathrm{kg} / \mathrm{m}^{3}$.

Gőzök esetén adott nyomásviszonyok között a szelepen átáramló térfogatáram kritikus alatti a nyomásviszony esetén, azaz az egyszerüsített gyártói ajánlások szerint $P_{2}>\frac{P_{1}}{2}$ :

$$
Q=\frac{31,62 \cdot K_{V}}{\sqrt{\frac{1}{\left(P_{1}-P_{2}\right) \cdot \rho_{2}}}}
$$

Kritikus állapotot elérő gőzáramlás esetén, azaz $P_{2}<\frac{P_{1}}{2}$ teljesülésekor a térfogatáram:

$$
Q=\frac{31,62 \cdot K_{V}}{\sqrt{\frac{2}{P_{1} \cdot \rho^{*}}}}
$$

ahol

$Q \quad$ a szelepen átjutó gáz tömegárama, $\mathrm{kg} / \mathrm{h}$;

$K_{V}$ adott szelepnyitás melletti átfolyási tényezö;

$P_{1} \quad$ a szelep belépő oldali nyomása, bar $_{\mathrm{a}}$;

$P_{2} \quad$ a szelep kilépö oldali nyomása, bar $_{a}$;

$T$ a gáz hőmérséklete a szelep belépő oldalán, $\mathrm{K}$;

$\rho_{2} \quad$ a gáz kilépő oldali sűrüsége ( $T$ hőmérsékleten és $P_{2}$ nyomáson), $\mathrm{kg} / \mathrm{m}^{3}$;

$\rho^{*} \quad$ a gáz kritikus állapotbeli sürüsége ( $T$ hőmérsékleten és $P_{1} / 2$ nyomáson), $\mathrm{kg} / \mathrm{m}^{3}$.

Sok esetben a veszélyes állapot kialakulása esetén lefúvatandó tömegáram meghatározására is ezeket az összefüggéseket használja az ipari gyakorlat a maximális $K_{V}$ ismeretében, ám a tapasztalat azt mutatja, hogy ezek az eredmények nem minden esetben a szabvány szerint meghatározott értékeket adják eredményül, így alkalmazásuk biztonságtechnikai szempontból aggályos. 


\section{Az EN 60534 szabvány összefüggései}

Az EN 60534 szabvány [4] a számítási összefüggések során kitér a nem turbulens áramlásokra is. Azonban munkánk során ennek a vizsgálatától eltekintettünk, ugyanis biztonságtechnikai szempontból a maximális tömegáram megállapítása a cél, adott átfolyási tényező és maximális nyitottság mellett. Ezért a szabványi összefüggéseket a tömegáram meghatározásához rendeztük át. Ugyanezeket az öszszefüggéseket alkalmazza a Crane, mint szabályozó szelep gyártó is. [8]

A szabvány nem összenyomható közegek esetén is figyelembe veszi, hogy a közeg a szelepen belül eléri-e a kritikus állapotot az áramlása során, vagy nem. Ennek megfelelöen megkülönböztet „choked flow” és „non-choked flow”-ra érvényes összefüggéseket.

\subsection{Nem összenyomható közegek}

Nem gázdinamikai értelemben vett összenyomhatatlan közegek, tipikusan folyadékok esetén a kritikus állapotot el nem érő áramlásokra a következő feltétel teljesül:

$$
\Delta P \leq F_{L}^{2}\left(P-F_{F} P_{V}\right)
$$

ahol a korábbiakban ismertetetteken felül

$\Delta P$ a szabályozó szelep két oldalán fellépő nyomáskülönbség, bar;

$F_{L}$ az úgynevezett „liquid pressure recovery factor”, amely a szelep belső geometriájának hatását fejezi ki a szelepkapacitásra, kritikus áramlás mellett. Értéke a szabványban közölt diagramok segítségével a szeleptípus és a nyitottság függvényében meghatározható.

$F_{F}$ az úgynevezett „liquid critical pressure ratio factor”, amely a ,vena contracta” azaz a sugárösszehúzódás hatását fejezi ki a folyadék gőznyomására a belépési hőmérsékleten, kiszámítása:

$$
F_{F}=0,96-0,28 \sqrt{\frac{P_{V}}{P_{c}}}
$$

$P_{V}$ a közeg abszolút gőznyomása a belépő hőmérsékleten, $\mathrm{kPa}$;

$P_{c}$ a közeg abszolút termodinamikai kritikus nyomása, $\mathrm{kPa}$.

Ekkor a kritikus állapotot el nem érő áramlás esetén, az adott feltételek mellett a szabályozó szelepen átáramló $Q$ folyadék térfogatáram a következőképpen számítható:

$$
Q=\frac{N_{1} K_{V}}{\sqrt{\frac{\rho_{1} / \rho_{0}}{\Delta P}}}
$$

Ebböl a $W$ tömegáram minden esetben:

$$
W=Q \cdot \rho_{1}
$$

A fentebbi két összefüggésben:

$N_{1}$ a szabvány által megadott konstans; $N_{1}=1$, ha a térfogatáram $\mathrm{m}^{3} / \mathrm{h}$-ban, a nyomás pedig barban van megadva;

$\rho_{0}$ a $15^{\circ} \mathrm{C}$ hömérsékletü víz sürüsége légköri nyomáson, $\mathrm{kg} / \mathrm{m}^{3}$;

$\rho_{1}$ a közeg sürüsége a belépési nyomáson és hőmérsékleten, $\mathrm{kg} / \mathrm{m}^{3}$.

Amennyiben az áramlás a szelepen belül eléri a kritikus állapotot, azaz

$$
\Delta p>F_{L}^{2}\left(P_{1}-F_{F} P_{V}\right)
$$

a térfogatáram számítására szolgáló összefüggés: 


$$
Q=\frac{N_{1} \cdot F_{L} \cdot K_{V}}{\sqrt{\frac{\rho_{1} / \rho_{0}}{P_{1}-F_{F} P_{V}}}}
$$

\section{2 Összenyomható közegek}

Mivel általánosságban az elzárószelepek (nemzetközi szakirodalomban ezek „globe” néven szerepelnek) szelepek terjedtek el az ipari alkalmazásokban [9][10][11], ezért az összenyomható közegek nyomásszabályozása során vizsgált referencia-szelep az ARI-STEVI Pro 470/471 típusú DN80 méretü „V-port plug” kialakítású elzárószelep volt, melynek $K_{V S}$ értéke 100, maximális nyomáskülönbsége levegőre 30 bar, a minimális táplevegő-nyomása pedig 2 bar. [12] Az alábbi összefüggésekben használt szelepspecifikus konstansok kiválasztásánál ennek tulajdonságait vettük figyelembe.

Az összenyomható közegek, jelen esetben gázok és gőzök esetén a kritikus alatti áramlás felső határát a következő összefüggéssel határozza meg a szabvány:

$$
\mathrm{x}<F_{\gamma} x_{T}
$$

ahol

$\mathrm{x}$ a nyomáskülönbség és a belépő oldali nyomás aránya: $x=\left(P_{1}-P_{2}\right) / P_{1}$;

$F_{\gamma}$,specific heat ratio factor”, a közeg izetnropikus kitevőjének viszonya a levegőhöz képest: $F_{\gamma}=\gamma / 1,4$ ahol $\gamma$ a közeg izentropikus kitevője.

$x_{T}$,pressure differential ratio”, a nyomáskülönbségi arány, amely a szabványból meghatározható érték a szelep típusától függően.

Kritikus alatti áramlás esetén a szabályozó szelepen átmenő $W$ tömegáram:

$$
W=N_{6} \cdot Y \cdot K_{V} \cdot \sqrt{x \cdot P_{1} \cdot \rho_{1}}
$$

ahol a már ismert jelöléseken kívül

$N_{6}$ a szabvány által megadott konstans; $N_{6}=31,6$, ha a tömegáram $\mathrm{kg} / \mathrm{h}$-ban, a nyomás bar-ban, a sürüség pedig $\mathrm{kg} / \mathrm{m}^{3}$-ben van megadva;

$Y$ az expanziós faktor: $Y=1-\frac{x}{3 \cdot F_{\gamma} \cdot x_{T}}$.

A kritikus állapotot a szelepben elérő áramlás esetén a következő összefüggés használható a $W$ tömegáram számítására:

$$
W=0,667 \cdot N_{6} \cdot K_{V} \cdot \sqrt{F_{\gamma} \cdot x_{T} \cdot P_{1} \cdot \rho_{1}}
$$

\section{A vizsgált közegek és azok paraméterei}

Az összefüggések ellenőrzését összenyomhatatlan közegekre vízre, míg az összenyomható közegekkel kapcsolatos számításokat nitrogénre végeztük el.

Mindkét esetben az egyenként $20^{\circ} \mathrm{C}$ hőmérsékletü közegek kilépő nyomását 2 bar $_{\mathrm{a}}$-ra választottuk, míg a belépő nyomás értékét 3 bar $_{\mathrm{a}}$ és 30 bar $_{\mathrm{a}}$ között változtattuk. A vizsgált elzárószelepek („globe valve") az iparban általánosan elterjedt szabályozó szelepcsoport. Ezeket a biztonságtechnikai vizsgálatok során 100\%-os nyitottságúnak feltételezzük, így azt az esetet vizsgáltuk és ebben az állásban a vizsgálataink során a $K_{V S}=100$ értéket veszik fel, így az összefüggésekbe minden esetben a $K_{V}$ helyére ez az érték került. Az egyenletekbe helyettesítendő speciális paraméterek a választott referenciaszelep adatai alapján a következők: 
A $\Delta P \leq F_{L}^{2}\left(P-F_{F} P_{V}\right)$

(8(8) egyenletben szereplö $F_{L}$ „liquid pressure recovery factor" értékét az EN 60534 szabvány szerint az abban közölt diagramok alapján 0,9-re választottuk.

A (14) egyenletben szereplö $F_{\gamma}$,specific heat ratio factor” értéke nitrogén közegre a szabvány szerint 1, hiszen a $\gamma$ izentropikus kitevő értéke szintén szabványi táblázatból megállapítható konstans érték, nitrogén esetén 1,4. A szabvány nem veszi figyelembe az izentropikus kitevő változását [13] a nyomás és a hőmérséklet függvényében, így mi sem tesszük.

A szintén a (14) összefüggésben szereplő $x_{T}$,pressure differential ratio”, nyomáskülönbségi arány, értéke az általunk választott referencia-szelepnek megfelelően 0,7 .

\section{Számítási eredmények}

A gyártói ajánlások és a szabványi előírások szerinti számításokat a Matlab szoftver segítségével végeztük el a $P_{1}=3.30$ bar $_{a}$ nyomástartományban és $P_{2}=2$ bar $_{a}$ érték mellett. A számítások során figyelembe vettük az összenyomható közeg sürüségváltozását a belépési pontban.

Korábbi ipari megbízásaink során az egyszerüsített gyártói előírások alapján számított kapacitások ellenőrzését láttuk célszerünek az Ari MyValve szelepméretező szoftverrel, valamint általános felhasználású ChemCad szoftver segítségével is.

Az előbbi az ARI Armaturen szerelvénygyártó és forgalmazó vállalat saját szoftvere, melynek segítségével a kívánt követelmények kielégítésére alkalmas szelepek méretezése és kiválasztása végezhető. Az ebben vizsgált referencia-szelep az ARI-STEVI Pro 470/471 típusú DN80 méretü „V-port plug" ülékkialakítású elzárószelep volt, melynek $K_{V S}$ értéke 100, maximális nyomáskülönbsége levegőre 30 bar, a minimális táplevegő-nyomása pedig 2 bar. [12]

Az utóbbi a Chemstations Inc. terméke, amely egy általános célú kémiai tervező és folyamatmodellezö szoftvercsomag, és amely szerelvények, készülékek és technológiai rendszerek modellezésére jött létre. [14] A modellezés során 100\%-os nyitottságú szabályozó szelepet vizsgáltunk az adott nyomásviszonyok és elöre magadott $K_{V}=100$ átfolyási tényező mellett, a számításokkal egyező paraméterek alkalmazásával. A számítások és szimulációk eredményeit a 2. ábra és a 3. ábra szemlélteti.

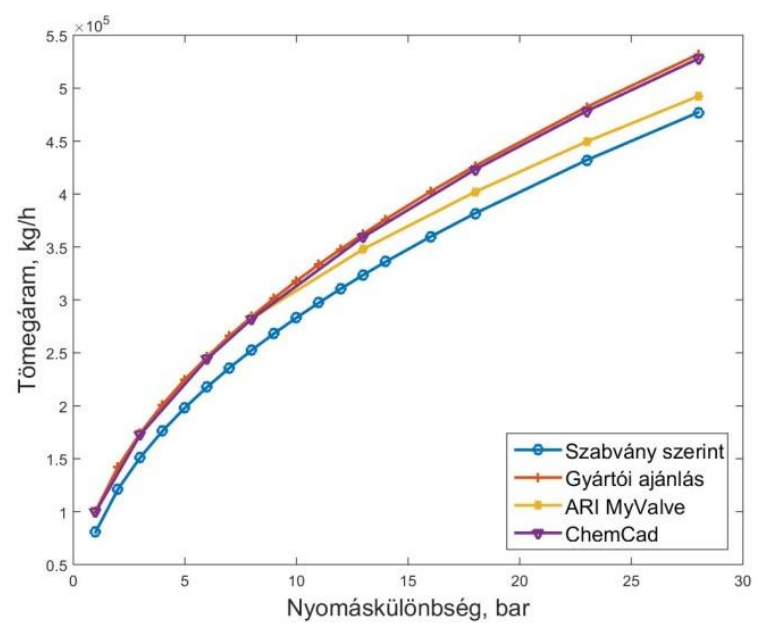

2. ábra Számitási és szimulációs eredmények összevetése nem összenyomható közegek esetén A vizsgált közeg $20^{\circ} \mathrm{C}$ hömérsékletü viz, 2 bar a kilépö nyomással 
Ahogyan a 2. ábran megfigyelhető, hogy a szabvány szerinti számítások eredményeit az adott esetekre mindhárom egyéb módszer felülről becsüli, így ilyen esetekben ezen egyéb módszerek is biztonsággal alkalmazhatók.

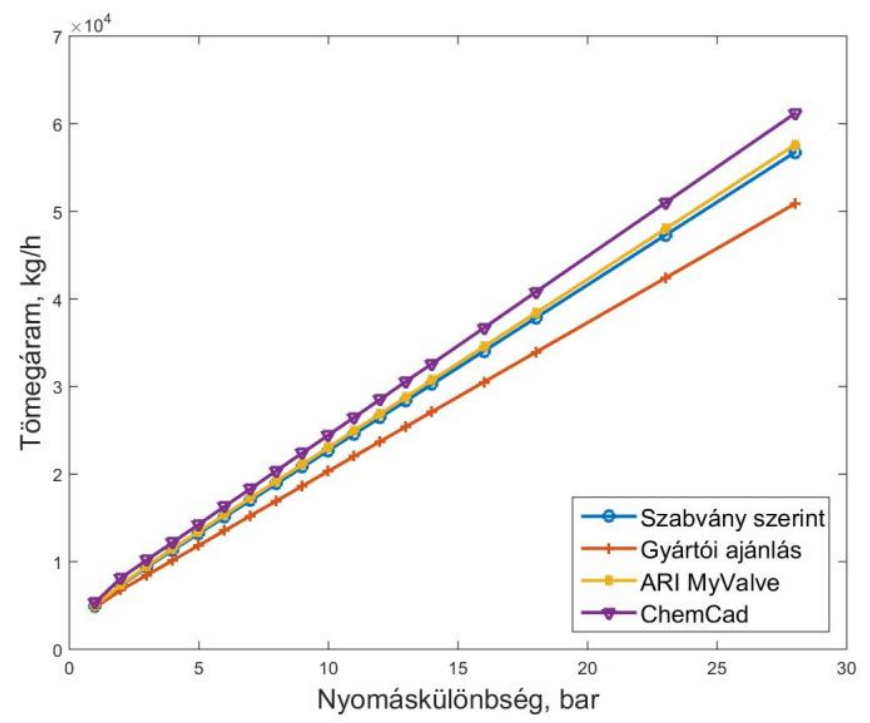

3. ábra Számitási és szimulációs eredmények összevetése összenyomható közegek esetén A vizsgált közeg $20^{\circ} \mathrm{C}$ hömérsékletü nitrogén, 2 bar a kilépö nyomással

A 3. ábraán látható, hogy ChemCad szoftver segítségével számított értékek mindhárom egyéb módszer szerint meghatározott tömegáram-értékeket meghaladják. Ezzel szemben az egyszerüsített gyártói ajánlások szerinti számítások adták a legalacsonyabb értékeket.

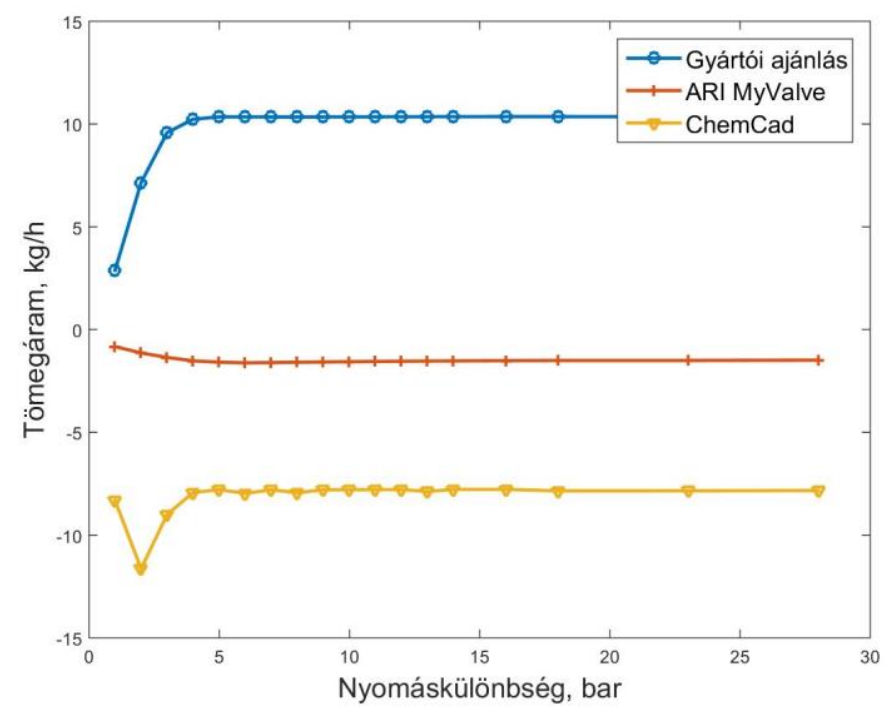

4. ábra A szabványtól eltérö módszerek szerint számitott tömegáramok százalékos eltérése a szabványi számitáshoz képest 
Megfigyelhető továbbá, hogy az Ari MyValve szoftver segítségével kapott adatok jól közelítik az EN 60534 által meghatározott tömegáramokat, az eltérések a szabványhoz képest a vizsgált paraméterek mellett minden esetben 5\% alatt maradtak. (4. ábra) Mivel a szabványi számítást helyesen elvégezve azokat a mérnöki gyakorlatban általánosan elfogadjuk mint a valóságot a biztonság irányából közelítő eljárást, ezért elmondható, hogy az Ari MyValve és az EN 60534 szerinti számítások alkalmasak a szabályozó szelepeken átjutó tömegáram meghatározására valamint a biztonsági szelepek lefúvókapacitásának méretezésére.

Az egyszerüsített ajánlások alapján elvégzett számítások önmagukban nem alkalmazhatók biztonsággal biztonsági szelep lefúvókapacitásának méretezésére. A szabványi számításokhoz képest ezek a vizsgált paraméterek mellett esetenként 10\%-os eltérést is mutatnak (4. ábra).

Amennyiben egyszerüsített számításokat kívánunk végezni, úgy nitrogén közeg esetén az ajánlás szerint számított szükséges lefúvatandó tömegáram-értékeket a biztonságtechnikai méretezés során célszerü legalább 15-20\%-kal megnövelni a biztonság javára tévedve, míg víz esetén az egyszerüsített számítás során kapott tömegáram-értékek akár csökkenthetők is.

\section{7. Összefoglalás}

Ipari megbízások teljesítése közben merült föl a probléma, miszerint az egyes szabályozó szelepgyártó cégek által ajánlott egyszerüsített méretezési segédlet alapján meghatározott, az adott szelepen átáramló maximális tömegáram alulbecsüli mind a valós, mind az EN 60534 szerint számított értéket, így biztonságtechnikai számítások elvégzésére nem, vagy csak korlátozottan alkalmas. Jelen cikkünkben összevetettük ezeket az ajánlásokat a tényleges EN 60534 szabvány szerinti számításokkal, valamint az ARI Armaturen szerelvénygyártó vállalat saját méretezőszoftverének eredményeivel, és az ezektől független ChemCad szimulációs szoftver által adott eredményekkel. Vizsgálataink során folyadék és gáz halmazállapotú közegre is elvégeztük a számításokat és a szimulációkat. A folyadék halmazállapotú közeg víz volt, míg a gáz halmazállapotú közeg nitrogén. Mindkét esetben $20^{\circ} \mathrm{C}$ hömérsékletủ közeget vizsgáltunk 2-30 bar $_{\mathrm{a}}$ belépési nyomástartományon 2 bar $_{\mathrm{a}}$ elvárt kilépési nyomás mellett.

A vizsgálatok kimutatták, hogy víz közeg esetén az adott körülmények között lefúvatott tömegáramok a gyártói ajánlások szerint számított és a ChemCad szoftverrel végzett szimulációk esetén adják a legmagasabb értékeket, meghaladva még a szabványi ajánlások szerint számított eredményeket is. Így biztonságtechnikai vizsgálatok esetén ezek a módszerek biztonsággal használhatók a maximális lefúvatandó tömegáram meghatározására, mert a biztonság irányába tévedve túlbecsülik a szabvány szerint számított eredményeket.

Nitrogén közeg esetén a vizsgált paraméterek mellett az eltérő számítási módszerek eredményei más elrendeződést mutattak, mint a víz esetén. A legmagasabb tömegáram-értékeket a ChemCad segítségével elvégzett számítások adták, míg a legalacsonyabbat a gyártói ajánlások szerint számított eredmények. Ez remekül példázza azt is, hogy az ipari gyakorlattól eltérően ez utóbbi önmagában nem alkalmazható biztonságtechnikai vizsgálatok elvégzésére. Azonban gyors becslések során a szükséges lefúvatandó tömegáram meghatározására célszerủ 15-20\%-kal megnövelni a gyártó ajánlások szerint meghatározott tömegáram-értékeket.

Mivel a jelenlegi vizsgálatok csak kis számú anyagtípusra és korlátozott nyomástartományon lettek elvégezve, így mindössze ezekre a konkrét esetekre alkalmazhatók. 


\section{Köszönetnyilvánítás}

A cikkben ismertetett kutató munka az EFOP-3.6.1-16-2016-00011 jelü „Fiatalodó és Megújuló Egyetem - Innovatív Tudásváros - a Miskolci Egyetem intelligens szakosodást szolgáló intézményi fejlesztése" projekt részeként - a Széchenyi 2020 keretében - az Európai Unió támogatásával, az Európai Szociális Alap társfinanszírozásával valósul meg.

\section{Irodalom}

[1] API 520, "Sizing, Selection, and Installation of Pressure-Relieving Devices in Refineries Part I-Sizing and Selection," p. 100, 2000.

[2] Bozóki, G. Nyomástartó rendszerek túlnyomáshatárolása. Budapest: Müszaki Könyvkiadó, 1977.

[3] Bohl, W. Müszaki áramlástan. Budapest: Müszaki Könyvkiadó, 1983.

[4] EN60534-2, "Flow Equations for Sizing Control Valves." p. 72, 2007.

[5] Samson, Application Notes: KV coefficient, Valve sizing, no. March. 2012.

[6] Engineering Toolbox, "Flow coefficients Kv for Liquid, Steam or Gas," 2020. [Online]. Available: https://www.engineeringtoolbox.com/kv-coefficients-d_1931.html. [Accessed: 06Apr-2020].

[7] Cioncolini, A., Scenini, F., Duff, J., Szolcek, M., Curioni, M. Choked cavitation in microorifices: An experimental study,. Exp. Therm. Fluid Sci. 2016, 74:49-57. https://doi.org/10.1016/j.expthermflusci.2015.12.004

[8] Crane Co., Flow of Fluids. Stamford, 2010. https://doi.org/10.1016/S1359-6128(10)70023-9

[9] Ecoe Excellence Engineering Centre, General Control valves., no. July. 2011.

[10] Emerson and Fisher, Control valve handbook, 5th ed. 2019.

[11] Koso and Parcol, Handbook for Control Valve Sizing. 2013.

[12] ARI Armaturen, Ari-stevi ® 470 / 471 (dn15-150) termékkatalógus, vol. 471. 2017.

[13] Kouremenos, D. A., Antonopoulos, K. A. Isentropic exponents of real gases and application for the air at temperatures from $150 \mathrm{~K}$ to $450 \mathrm{~K}$. Acta Mech. 1987, 65(1-4):81-99. https://doi.org/10.1007/BF01176874

[14] Némethné Sóvágó, J. A vegyipari szimulációs programok müködéséhez alkalmazható termodinamikai modellek. Anyagmérnöki Tudományok 2013,38(1):231-243. 